\title{
PENGARUH PENDIDIKAN KESEHATAN TERHADAP PENGETAHUAN DAN KETERAMPILAN DALAM PERAWATAN PAYUDARA PADA IBU POST PARTUM DI RS Dr. OEN SURAKARTA
}

\author{
Oleh : \\ Sri Aminingsih ${ }^{1}$ Warsini $^{2}$, Umi Padmiati ${ }^{3}$
}

\begin{abstract}
Background. Health education is a planned process of change in behavior on the individual or community to be more self-sufficient in achieving life goals se, attitudes and community practices in maintaining and improving health.

The purpose to determine the effect of health education on the knowledge and skills in the treatment of breast in women post partum

Method using pre post experimental with a total sample of 25 respondents. The result showed no conclusions on the effect of health education knowledge and skills in the treatment of breast in women postpartum hospital. Dr. Oen Surakarta. This is evidenced by the amount of $0.01 \mathrm{t} \alpha=9.313$ and $\mathrm{t}$ table $=$ 2.797 for knowledge, while for the results obtained skills $t \alpha 0,01=10.303$ and $t$ table $=2.797$. This study data analysis using Paired Test.

The conclusion. There pendidikanpendidikan influence the health of the knowledge and skills in the treatment of breast in women postpartum in RS Dr. Oen Surakarta.
\end{abstract}

Keywords : Health education, knowledge of breast care and breast care skills

\section{PENDAHULUAN}

Kesehatan merupakan salah satu aspek dari kehidupan masyarakat. Mutu hidup, produktifitas kerja, angka kesehatan, dan kematian yang tinggi pada bayi dan anakanak, menurunnya daya fisik serta terganggunya perkembangan mental adalah akibat langsung atau tidak langsung dari masalah gizi kurang. Salah satu masalah gizi yang paling utama pada saat ini adalah kurang kalori protein yang banyak ditemukan pada bayi dan anak-anak. Terjadinya kerawanan gizi pada bayi selain karena makanan yang kurang juga disebabkan karena kurang mendapat Air Susu Ibu (ASI).

Diperkirakan $80 \%$ dari jumlah ibu yang melahirkan ternyata mampu menghasilkan air susu dalam jumlah yang cukup untuk keperluan bayinya secara penuh tanpa makanan tambahan. Sebelum susu yang sebenarnya muncul, payudara ibu menghasilkan kolostrum, yaitu suatu cairan yang mengandung antibody dan nutrisi penting untuk bayi. ASI sebagai makanan terbaik bagi bayi tidak dapat diragukan lagi, namun akhir-akhir ini banyak diantara ibuibu tidak mau memberikan ASInya. Berbagai alasan dikemukakan oleh ibu-ibu mengapa keliru dalam pemanfaatan ASI secara eksklusif antara lain karena produksi ASI kurang, kesulitan bayi dalam menghisap, keadaan puting susu yang menunjang, ibu bekerja, keinginan untuk disebut modern dan pengaruh iklan.

Pada ibu menyusui sangat
diharapkan untuk melakukan
perawatan payudara pada masa
menyusui, karena perawatan
payudara juga akan mempengaruhi
produksi dan kelancaran ASI, selain
itu payudara akan senantiasa bersih,


sehat, dan mudah diserap oleh bayi. Pada bayi yang tidak melakukan perawatan payudara banyak kemungkinan akan mempunyai masalah dalam masa menyusuinya, diantaranya seperti nyeri puting, payudara bengkak, dank eras, putting lect atau retak dan air susu rembes (http://www.infobunda.com)

Pengetahuan dan keterampilan ibu dalam perawatan payudara dapat ditingkatkan melalui pendidikan kesehatan. Selama ini di ruang Mawar-Melati Rumah Sakit Dr.Oen Surakarta sudah dilakukan pendidikan kesehatan perawatan payudara bagi ibu post partum, akan tetapi pemberian pendidikan kesehatan tersebut belum diketahui keefektifitasannya.

\section{METODE PENELITIAN}

Penelitian ini menggunakan desain pre-post eksperimental, yaitu mengungkapkan hubungan sebab akibat dengan cara melibatkan dua kelompok subyek serta membandingkan hasil pra test dengan pasca test. Dalam penelitian ini peneliti memberikan pretest untuk mengetahui pengetahuan dan ketrampilan ibu post partum tentang perawatan payudara, kemudian peneliti memberikan penkes perawatan payudara dan setelah perlakuan peneliti melakukan pengukuran lagi untuk mengetahui pengaruh dari penkes yang diberikan. Populasi dalam penelitian ini adalah semua ibu post partum yang dirawat di ruang Mawar Melati RS Dr. Oen Surakarta.Sampel dalam penelitian ini adalah $25 \mathrm{lbu}$ post partum.

\section{HASIL PENELITIAN}

Berdasarkan penelitian yang telah dilakukan mulai bulan April sampai bulan Agustus 2013 didapatkan karakteristik responden berdasarkan usia, tingkat pendidikan dan hari dirawat beserta hasil penelitian mengenai pengaruh pendidikan kesehatan terhadap pengetahuan dan ketrampilan dalam perawatan payudara pada ibu post partum di RS Dr. Oen Surakarta, yaitu sebagai berikut :

Tabel 1. Distribusi Frekuensi Karakteristik Responden Berdasarkan Usia

\begin{tabular}{ccc}
\hline $\begin{array}{c}\text { Kelompok } \\
\text { usia }\end{array}$ & frekuensi & $\%$ \\
\hline $15-20$ & 1 & 4 \\
$21-25$ & 7 & 28 \\
$26-30$ & 12 & 48 \\
$31-35$ & 1 & 4 \\
$36-40$ & 3 & 12 \\
$>40$ & 1 & 4 \\
\hline Jumlah & 25 & 100 \\
\hline
\end{tabular}

Dari data di atas diperoleh informasi bahwa sebagian besar responden $(48 \%)$ berada pada kelompok umur 26-30 tahun dan jumlah responden paling sedikit (4\%) berada pada kelompok umur 15-20 tahun, 31-35 tahun dan $>40$ tahun

Tabel 2. Tabel Distribusi Frekuensi Responden Berdasarkan Tingkat

\begin{tabular}{ccc}
\multicolumn{3}{c}{ Pendidikan } \\
\hline Tingkat & Frekuensi & $\%$ \\
Pendidikan & & 8 \\
\hline SMP & 2 & 52 \\
SMA & 13 & 8 \\
D1 & 2 & 16 \\
D3 & 4 & 16 \\
S1 & 4 & 100 \\
\hline Jumlah & 25 &
\end{tabular}

Dari data di atas diperoleh informasi bahwa sebagian besar tingkat pendidikan responden adalah SMA $(52 \%)$ dan prosentase terkecil tingkat pendidikan responden adalah SMP dan D1 (2\%)

Tabel 3. Distribusi Frekuensi Karakteristik Responden Berdasarkan hari Dirawat

\begin{tabular}{ccc}
\hline $\begin{array}{c}\text { Hari } \\
\text { Dirawat }\end{array}$ & frekuensi & $\%$ \\
\hline Hari ke 1 & 19 & 76 \\
Hari ke 2 & 6 & 24 \\
\hline Jumlah & 25 & 100 \\
\hline
\end{tabular}


Dari data di atas diperoleh informasi bahwa sebagian besar responden dirawat pada hari ke 1 (76\%)

1. Pengaruh pendidikan kesehatan terhadap pengetahuan

Tabel 4. Skor pengetahuan sebelum dan sesudah diberi penkes

\begin{tabular}{ccc}
\hline Skor & $\begin{array}{c}\text { Sebelum } \\
\text { penkes }\end{array}$ & $\begin{array}{c}\text { Sesudah } \\
\text { penkes }\end{array}$ \\
\hline Mean & 15,36 & 19,16 \\
Minimum & 11 & 16 \\
Maksimum & 19 & 20 \\
Standar deviasi & 2,46 & 1,02 \\
\hline
\end{tabular}

Dari tabel di atas dapat diketahui bahwa skor rata-rata pengetahuan responden sesudah diberi penkes $(19,61)$ lebih tinggi dari pada sebelum diberi penkes $(15,36)$. Skor minimum responden sesudah diberi penkes (16) lebih tinggi daripada sebelum diberi penkes (11). Skor maksimum responden sesudah diberi penkes (20) lebih tinggi dari pada sebelum diberi penkes (19).

Dari hasil uji dengan Paired T-test diperoleh t hitung sebesar 9,313. Hasil tersebut dikonsultasikan dengan $\mathrm{t}$ tabel pada $\mathrm{dk}: 24$ diperoleh $t$ tabel sebesar 2,797 untuk $\mathrm{p}$ value $1 \%$ dan 2,064 untuk $p$ value $5 \%$. Dari hasil tersebut diketahui $\mathrm{t}$ hitung $>\mathrm{t}$ tabel. Sehingga dapat disimpulkan bahwa $\mathrm{Ha}$ diterima dan $\mathrm{Ho}$ ditolak, yang berarti ada pengaruh pendidikan kesehatan terhadap pengetahuan dalam perawatan payudara pada ibu post partum
2. Pengaruh kesehatan pendidikan keterampilan

Tabel 5. Skor keterampilan sebelum dan sesudah diberi penkes

\begin{tabular}{ccc}
\hline Skor & $\begin{array}{c}\text { Sebelum } \\
\text { penkes }\end{array}$ & $\begin{array}{c}\text { Sesudah } \\
\text { penkes }\end{array}$ \\
\hline Mean & 71,2 & 95 \\
Minimum & 40 & 80 \\
Maksimum & 90 & 100 \\
Standar deviasi & 13,63 & 6,29 \\
\hline
\end{tabular}

Dari tabel di atas dapat diketahui bahwa skor rata-rata keterampilan responden sesudah diberi penkes (95) lebih tinggi dari pada sebelum diberi penkes $(71,2)$. Skor minimum responden sesudah diberi penkes (80) lebih tinggi daripada sebelum diberi penkes (40). Skor maksimum responden sesudah diberi penkes (100) lebih tinggi dari pada sebelum diberi penkes (90).

Dari hasil uji dengan Paired T-test diperoleh t hitung sebesar 10,303. Hasil tersebut dikonsultasikan dengan $\mathrm{t}$ tabel pada $\mathrm{dk}: 24$ diperoleh $t$ tabel sebesar 2,797 untuk $p$ value $1 \%$ dan 2,064 untuk $p$ value $5 \%$. Dari hasil tersebut diketahui $\mathrm{t}$ hitung $>\mathrm{t}$ tabel. Sehingga dapat disimpulkan bahwa $\mathrm{Ha}$ diterima dan $\mathrm{Ho}$ ditolak, yang berarti ada pengaruh pendidikan kesehatan terhadap keterampilan dalam perawatan payudara pada ibu post partum.

Jadi dapat disimpulkan bahwa ada pengaruh pendidikan kesehatan terhadap pengetahuan dan keterampilan dalam perawatan payudara pada ibu post partum.

\section{PEMBAHASAN}

Dari hasil penelitian diperoleh kesimpulan bahwa ada pengaruh pendidikan kesehatan terhadap pengetahuan dan keterampilan dalam perawatan payudara pada ibu post partum di RS Dr. Oen Surakarta. Hal tersebut dapat terjadi karena dipengaruhi beberapa faktor dari responden sendiri dan dari 
pemberi pendidikan kesehatan. Dilihat dari karakteristik responden berdasarkan umur sebagian besar (48\%) berada di kelompok umur 2630 tahun, dimana pada umur tersebut responden cukup dapat bersikap dewasa dalam menerima informasi yang baru diketahuinya. Berdasarkan tingkat pendidikannya sebagian besar responden (tingkat pendidikannya adalah menengah ke atas (52\%), hal tersebut menunjukkan bahwa orang berpendidikan lebih mudah menerima informasi atau pengetahuan baru.

Dari hasil skor pengetahuan ibu sebelum diberi pendidikan kesehatan rata-rata adalah 15,36, sedangkan setelah diberi pendidikan kesehatan skor yang diperoleh terjadi peningkatan rata-rata menjadi 19,16. Hal ini menunjukkan bahwa pendidikan kesehatan tentang perawatan payudara bisa dikatakan sangat dibutuhkan oleh ibu post partum karena dengan pengetahuan yang benar ibu akan melakukan perawatan payudara.

Sedangkan skor keterampilan perawatan payudara sebelum diberi pendidikan kesehatan sebesar 71,2 dan setelah diberi pendidikan kesehatan sebesar 95. Dari hasil tersebut sangat sesuai dengan tingkat pengetahuan ibu post partum. Apabila pengetahuan meningkat maka ibu post partum akan cenderung untuk melakukan tindakan perawatan payudara.

Sedangkan sesuai hari di rawat yang sebagian besar responden (76\%) dirawat pada hari pertama, yang berarti bahwa responden masih memerlukan penyesuaian sebagai ibu khususnya dalam perawatan payudara selama menyusui bayinya. Hal tersebut membuat responden merasa perlu memperoleh informasi dalam perawatan payudara.

Melalui pendidikan kesehatan khususnya dalam perawatan payudara responden diberi suatu pengetahuan baru yang belum diketahuinya agar mereka menjadi terpengaruh dan dapat berperilaku sesuai dengan apa yang dikehendaki peneliti yaitu berupa keterampilan. Sesuai dengan yang dikemukakan oleh Soekidjo Notoadmodjo (2003) bahwa seseorang akan memberikan respon terhadap stimulus (rangsangan) yang diterima berupa suatu tindakan atau praktek. Artinya disini peneliti memberikan stimulus berupa pengetahuan baru, yang akan dinilai oleh responden. Kemungkinan besar responden merasa perlu memperoleh pengetahuan baru sehingga responden memberikan respon bahwa hal tersebut layak diterima dan dilakukan. Hal ini ditunjukkan dengan skor pengetahuan dan keterampilan responden setelah diberi pendidikan kesehatan lebih tinggi daripada sebelum diberi pendidikan kesehatan. Sudah jelas bahwa pendidikan kesehatan disini mempengaruhi pengetahuan dan keterampilan seseorang.

Secara konsep pendidikan kesehatan adalah semua kegiatan untuk memberikan atau meningkatkan pengetahuan, sikap dan praktek masyarakat dalam memelihara dan meningkatkan kesehatan. (Soekidjo Notoadmodjo, 2003) Dari pengertian tersebut peneliti atau perawat disini berperan sebagai pendidik/pemberi pengetahuan sehingga terbentuk keterampilan baru pada responden.

Yang berarti bahwa responden dalam hal ini adalah ibu post partum yang awalnya berpengetahuan minimal tentang perawatan payudara menjadi meningkat pengetahuannya setelah diberi pendidikan kesehatan. Kemudian dengan peningkatan pengetahuan ibu post partum tersebut akan lebih memotivasi ibu post partum untuk melakukan tindakan perawatan payudara sampai ASI keluar dengan 
lancar sehingga kebutuhan ASI pada bayi terpenuhi dan tumbuh kembang bayi bisa optimal.

\section{KESIMPULAN DAN SARAN}

1. Kesimpulan
a. Ada pengaruh pendidikan kesehatan terhadap pengetahuan dalam perawatan payudara pada ibu post partum di RS.Dr.Oen Surakarta.

b. Ada pengaruh pendidikan kesehatan terhadap keterampilan dalam perawatan payudara pada ibu post partum di RS.dr Oen Surakarta.

2. Saran

a. Bagi petugas kesehatan

$\begin{array}{lr}\text { Diharapkan } & \text { petugas } \\ \text { kesehatan } & \text { selalu }\end{array}$ memberikan pendidikan kesehatan pada ibu post partum tentang pentingnya perawatan payudara.

b. Bagi peneliti selanjutnya

Diharapkan

dapat melakukan mengenai penelitian pengetahuan perbedaan keterampilan ibu post partum antara yang diberi penkes dengan yang tidak diberi penkes.

\section{DAFTAR PUSTAKA}

Alimul H, A Aziz. Riset Keperawatan dan Tehnik Penulisan IImiah. Jakarta: Salemba Medika, 2003.

Arikunto, Suharsimi. Prosedur Penelitian Suatu Pendekatan Praktek. Jakarta: Rineka Cipta, 2003.

Budiarto, Eko. Biostatistika Untuk Kedokteran dan Kesehatan Masyarakat. Jakarta:EGC, 2002.
Ferrer, Helen. Perawatan Maternitas. Edisi 2. Alih Bahasa Andry Hartono. Jakarta: EGC, 1999.

Luwia, Melissa S. Problematik dan Perawatan Payudara. Jakarta: Kawan Pustaka, 2003.

Notoatmodjo, Soekidjo. Pendidikan dan Perilaku Kesehatan Jakarta: Rineka Cipta, 2003.

Nursalam dan Siti Pariani. Metodologi Riset Keperawatan. Jakarta: Sagungn Seto, 2001.

Sugiono. Statistika Untuk Penelitian. Bandung: CV.Alfabeta, 2003.

Suliha, Herawati, et al., Pendidikan Kesehatan Dalam Keperawatan. Jakarta: EGC, 2003.

Suyanto dan Ummi Salima. Riset Kebidanan Metodologi dan Aplikasi. Jogjakarta: Mitra Cendikia, 2008.

Dosen AKPER Panti Kosala Surakarta

2 Dosen AKPER Panti Kosala Surakarta

3 Dosen AKPER Panti Kosala Surakarta 